\title{
ヒラメ筋に対するストレッチング効果の筋電図学的解析 EMG Analysis of the Stretching Effect on the Soleus Muscle
}

\author{
中村 浩一 1,2) 兒玉 隆之 ${ }^{3)}$ 向野 義人 ${ }^{2)}$ 鈴木 重行 ${ }^{4}$ 福良 剛志 ${ }^{5)}$ 大和 千絵5) \\ Kouichi Nakamura ${ }^{1.2)}$, Takayuki Kodama3), Yoshito MukainO2), \\ Shigeyuki Suzuki ${ }^{4}$, Tsuyoshi FukURA ${ }^{5}$, Chie Yamato ${ }^{5}$
}

\begin{abstract}
要旨：本研究の目的は, ヒラメ筋に対するストレッチング効果を神経生理学的に明らかに することである。対象は，健常男子学生40名40肢左脚とした。方法は，ストレッチングを 課す条件（ストレッチ条件）と課さない条件（コントロール条件）から，誘発筋電図を用 いて $\mathrm{H}$ 波と M波の最大振幅から算出された最大振幅比（Hmax/Mmax）により，ヒラメ 筋の状態を評価し，条件間㧍よびストレッチング前後で比較検討した。結果は，条件間の 最大振幅比に有意差はみられないが, ストレッチング前に比ベストレッチング後は, 有意 に低值を示した。これらの知見から，個別的な筋へのストレッチングは従来の先行研究と 同様の神経生理学的変化をもたらす可能性が示唆される。

キーワード：ストレッチング，筋緊張，抑制

Abstract: This study aimed to clarify the neurophysiological effect of stretching to suppress muscle tone, involving 40 left legs of 40 healthy male students. Evoked electromyography was performed under 2 different conditions (stretch and control) to compare soleus muscle activity between the conditions and between before and after stretching, based on the maximum $\mathrm{H}$ - to $\mathrm{M}$-wave amplitude ratio ( $\operatorname{Hmax} / \mathrm{Mmax})$. While there were no significant differences in Hmax/Mmax values between the 2 conditions, a marked decrease in such values was observed after stretching, suggesting the possibility of such stretching suppressing the excitability of spinal motor neurons.
\end{abstract}

Key words: stretching, muscle tone, inhibitory

\footnotetext{
受付日：2014年 7 月 6 日，採択日：2014年 8 月 1 日

1) 福岡和白リハビリテーション学院 理学療法学科 福岡県福岡市東区和白丘 2 丁目 1 - 13 ( ₹811-0213) TEL 092-608-8600 Department of Physical Therapy, Fukuoka Wajiro Rehabilitation College: 2-1-13 Wajirogaoka, Higashiku, Fukuoka-city, Fukuoka 811-0213, Japan. TEL+8192-608-8600 E-mail:nakamura@fukuokawajiro-reha.jp

2) 福岡大学大学院 スポーツ健康科学研究科

Faculty of Sports and Health Science, Fukuoka University

3) 京都橘大学 健康科学部 理学療法学科

Department of Physical Therapy, Faculty of Health Sciences, Kyoto Tachibana University

4) 名古屋大学大学院 医学系研究科

Program in Physical and Occupational Therapy, Graduate School of Health Sciences, Nagoya University

5) 福岡和白病院 生理検査科

Department of Clinical Laboratory, Fukuoka Wajiro Hospital
} 


\section{I 、はじめに}

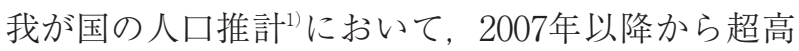
齢社会へ移行するなか, 従来の高度先進医療システム では早晚立ちゆかなくなることが予測される。厚生労 働省の「平成24年簡易生命表の概況」2)では, たとえ悪 性新生物 - 心疾患・脳血管疾患による早期死亡を根絶 し得たとしても, 平均寿命を約 $5-6$ 年程度延ばすこ としか寄与しないことが報告されている。これらの報 告は，寿命を延ばすことに対する生物学的限界が近づ いていることを意味する。つまり，医療の目的は，寿 命を延ばすことから，与えられた寿命をいかに良く生 きるか, いわば健康寿命に着眼し，「予防医学」を核 とする医療システムの構築が求められる。

予防医学的観点から見つめた場合, 高齢者からス ポーツ競技者抢よび愛好家に至るまで幅広く普及して いるものとして, ストレッチングが挙げられる。スト レッチングの目的は, 関節可動域 (柔軟性) の改善と 筋緊張の低下 ${ }^{3-10)}$, 血液循環の改善3,11,12), 筋痛の緩 和 ${ }^{3.13 .14)}$ ，障害予防・競技パフォーマンスの改善2.3.14) な どが共通してあげられる。現在では, Proprioceptive Neuromuscular Facilitation など神経系の反応を応用 したストレッチングがスポーツ領域で注目を浴びてい る。また，姿勢や呼吸法を重視するヨガやピラテイス とストレッチングを組み合わせて実施されるなど，ス トレッチングの種類や目的は多種多様であるが，その 一方でストレッチングの方法と効果の関連については, 未だ諸説 ${ }^{4-9}$ があり，議論の余地が残されている。

従来のストレッチングに扔ける研究報告 ${ }^{4-10)}$ は，八 ムストリングス，大腿四頭筋，下腿三頭筋といった筋 線維走行は異なるものの, 筋の名称により, ひとつの 方向から筋全体に対するストレッチングによってアプ ローチされたものであり，その中で効果を検証したも のである。しかしながら, 実際の臨床において, 理学 療法士は理学療法評価の過程から, 患者の治療対象と なる筋を特定し，個別的にアプローチすることが多い。 そこで我々は個別的に筋を伸張し，その効果を従来の スタティック・ストレッチングと比較検証した結果, 関節可動域（柔軟性）の増大および等速性筋出力の低 下，また，精神機能に対してはポジティブな見解が示 唆された ${ }^{15)}$ 。かし，これはあくまでパフォーマンス 上の変化であり, その数值が意味する背景を神経生理 学的に検討されていない。

そこで本研究は, 個別的に筋を伸張した際に筋緊張 へ及ぼす影響について誘発筋電図を用いて検証し，コ
ンディショニング領域における一端を神経生理学的に 明らかにすることを目的とした。

\section{II. 対象と方法}

\section{1. 対 象}

対象は, 下肢に神経障害の既往がない健常男子学生 40名とした。対象者の年齢，身長および体重は，20.6 \pm 3.2 歳, $172.6 \pm 4.8 \mathrm{~cm}, 64.5 \pm 5.4 \mathrm{~kg}$ （平均 \pm 標準偏 差）であった。測定は左下肢40肢に行い，対象筋は七 ラメ筋とした。

本研究は, すべての対象者に対し事前に口頭と文章 で研究の趣旨と内容, 得られたデー夕は研究の目的以 外に使用しないこと，個人情報の漏洩に注意すること， また研究への参加は自由意志であることを説明した。 すべての被験者は研究内容を理解した上で承諾書に署 名し, 研究に参加した。なお, 本研究は福岡保健学院 研究倫理委員会の承認を得た後に実施した。

\section{2. 方 法}

すべての対象者に対して，ヒラメ筋へのストレッチ ングを課す条件（ストレッチ条件）と，課さない条件 （コントロール条件）の 2 条件において， $\mathrm{H}$ 波と $\mathrm{M}$ 波 の最大振幅を測定した。なお，前の条件が次の条件で の結果に及ぼす影響を考慮して，ストレッチ条件とコ ントロール条件での実施には 1 日以上の間隔をあけた。 また，測定前に対象者の運動条件を整えるため，エル ゴメーター（5 min， 60w）を課した ${ }^{16.17) 。 ~}$

ヒラメ筋の $\mathrm{H}$ 波と $\mathrm{M}$ 波の導出には, 誘発筋電図(Viking Select, Nicolet 社製) を用いた。測定肢位は, いずれも腹臥位とした。誘発筋電図の刺激電極を膝窩 部に設置し, 脛骨神経に対して経皮的な電気刺激を 行った。脛骨神経に対する刺激は, 刺激頻度 $1 \mathrm{~Hz}$, 刺激持続時間 $1 \mathrm{msec} の$ 矩形波とした。導出電極には 表面電極を用い, 関電極は脛骨結節と足関節内果の中 間の位置で，脛骨のすぐ内側のヒラメ筋上に貼付した。 不関電極はアキレス腱の内側に貼付した。なお，アー スを刺激電極と関電極の中間点に貼付した。 $\mathrm{H}$ 波と $\mathrm{M}$ 波の測定は 5 分間の安静臥床後に 1 回, 各条件直後に 1 回測定した。測定は, 臨床検査技師 2 名（経験年数 $12.5 \pm 2.0$ 年）が行った。測定に際して，H波は室内 温度や皮膚温度による影響を受けやすいため, 室内温 度を $24^{\circ} \mathrm{C}$ 前後 ${ }^{16)}$ に維持し, 下腿中央部の皮膚温度は皮 膚温時計（IT-500S, HORIBA 社製）を用いて, $31^{\circ} \mathrm{C}$ $\sim 33^{\circ} \mathrm{C}$ で統一した。本研究では, $\mathrm{H}$ 波の最大振幅を $\mathrm{M}$ 
波の最大振幅で規格化を行い ${ }^{177}, \mathrm{H}$ 波と $\mathrm{M}$ 波の最大振 幅比を用いて検証を行った。

ストレッチ条件におけるヒラメ筋へのストレッチン グ方法は, Individual Muscle Stretching ${ }^{3}$ に準じ, 腹 臥位にて両上肢挙上位，膝関節 $90^{\circ}$ 屈曲位から膝関節 屈曲を増強しながらの足関節最大背屈とした。なお， ストレッチングを行う際の施行肢に加える外力を，客 観的で定量化可能な筋力評価に用いられるハンドヘル ドダイナモメーター（日本メディックス製品 FET102）を用い， $5 \mathrm{kgf}$ で制御した ${ }^{15)}$ 。ストレッチングの 施行時間 ${ }^{3}$ およひび回数は, 20 秒 $\times 3$ セットとし, 合計 1 分間のストレッチングを施行した。ストレッチング を行う者は, 我々とは別の理学療法士 2 名（経験年数 $10.5 \pm 2.0$ 年）が入れ替わり実施した。コントロール 条件はストレッチングを施行せず，ストレッチ条件と 同様の安静 ${ }^{15)}$ をった前後に測定を行った。

統計分析は，次のように実施した。要因として「ス トレッチングの有無（ストレッチ条件，コントロール 条件の 2 水準）および「測定時期（ストレッチング前, ストレッチング後の 2 水準)」の 2 要因に対し, $\mathrm{H}$ 波 およびM波の最大振幅比に対して二元配置反復測定分 散分析を行い, 多重比較には Bonfeeroni 検定を実施 した，統計解析ソフトゥェアは，SPSS19.0.J for Windows（SPSS，Japan）を使用し有意水準を $5 \%$ 未満 とした。

\section{III. 結 果}

「ストレッチングの有無」および「測定時期」で, $\mathrm{H}$ 波および $\mathrm{M}$ 波の最大振幅比（Hmax/Mmax）を比 較した結果, 交互作用が認められた $(\mathrm{F}(1,116)=$ 7. 14, p < 0. 05)。有意な主効果は, 「ストレッチング の有無」においては認められなかったが,「測定時期」 においては認められた $(\mathrm{F}(1,116)=4.62, \mathrm{p}<0.05) 。$ ストレッチングが筋緊張に影響を及ぼす可能性が示さ れた（表 1)。そこで「測定時期」について多重比較 を行ったところ、コントロール条件は有意差を認めな かったが，ストレッチ条件はストレッチング前に比較 し，ストレッチング後で最大振幅比が有意に低かった $(\mathrm{F}(3,116)=5.07, \mathrm{p}<0.05) （$ 表 1 , 図 1$)$ 。

\section{IV. 考 察}

本研究は, 個別的な筋へのストレッチングが筋緊張 に及ぼす影響について, 神経生理学的に検証し, コン デイショニング領域の一端を明らかにすることを目的
表 $1 \mathrm{H}$ 波のM波に対する最大振幅比

\begin{tabular}{ccc}
\hline 条件 & 前 & 後 \\
\hline ストレッチ & $0.37 \pm 0.13$ & $0.24 \pm 0.12^{*}$ \\
コントロール & $0.36 \pm 0.17$ & $0.37 \pm 0.15$ \\
\hline 前 : ストレッチング前, 後: ストレッチング後 \\
$\mathrm{n}=40$, 数值は\%, 平均士標準偏差, \\
${ }^{*} \mathrm{p}<0.05$ (ストレッチ前 vs ストレッチ後)
\end{tabular}

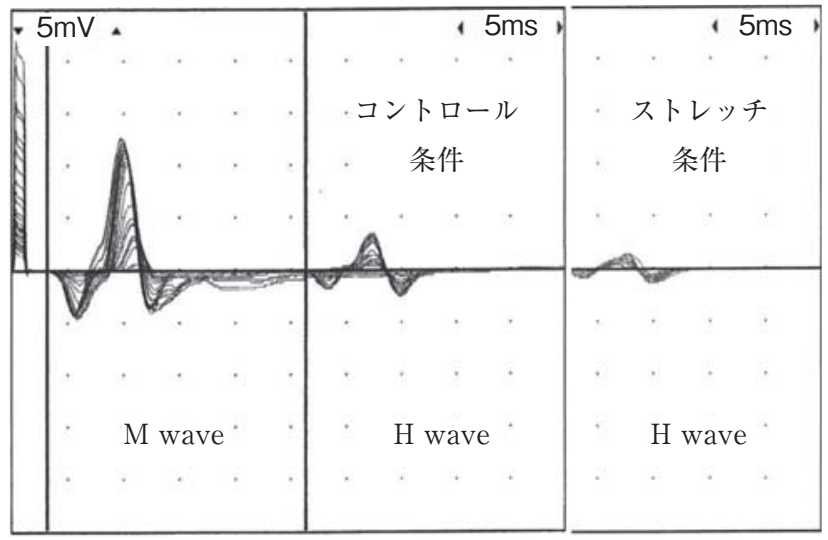

図 1 H波閾およびM波閾の最大振幅導出例

に実施した。

ストレッチング研究における誘発筋電図の代表的な 指標として，H波の振幅，およびH波のM波に対する 最大振幅比（Hmax/Mmax）が用いられる ${ }^{18)}$ 。誘発筋 電図で用いられるH波は, 太い有髄筋感覚神経 Ia 線 維を電気刺激して起こる単シナプス反射であり， $\mathrm{H}$ 波

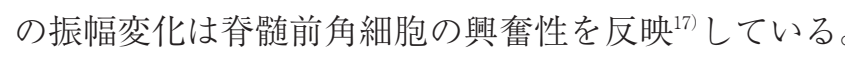
また，ヒトの筋緊張の調節は，主に伸張反射と自原性

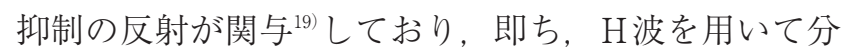
析することは脊髄および上位運動中枢の興奮準位を評 価する有効な手段である。臨床においては，筋緊張が 克進している患者ほどH波とM波の最大振幅比は高值 を示す ${ }^{20)}$ 。つまり, これらを踏まえ, 誘発筋電図は, 定量的な評価が難しいとされる筋緊張の評価を，より 客観的に行うことが可能といえる。

今回, ストレッチ条件の前後比較において, ストレッ チング前に比ベ，ストレッチング後は $\mathrm{H}$ 波およびM波 の最大振幅比が有意に低值を示す結果が得られた。こ のことから，ヒラメ筋に対するストレッチングは，従 来の先行研究 ${ }^{18)}$ と同様の神経生理学的変化をもたらす 可能性が示唆される。先行研究においても持続伸張が, 筋緊張を抑制あるいは低下させる報告がこれまで数多 く見られる ${ }^{21,22)}$ 。それらの背景として，筋が引き伸ば される時に，筋緊張の抑制に関与する末梢の受容器は ゴルジ腱器官, 関節受容器であり, 一般に筋腱移行部 
に多く存在するといわれているゴルジ腱器官からの $\mathrm{Ib}$ 神経線維は, 筋の張力に応じて興奮の程度が変化 する ${ }^{23}$ 。すなわち，筋に持続的な伸張が加わると主動 筋，共同筋に存在するゴルジ腱器官が興奮し，この信 号が求心性にIb 神経線維を伝播し脊髄後角に入り, 介在ニューロンを介して同名筋の脊髄前角細胞の興奮 を抑制する原理が働く。本研究においても, これらの 神経生理学的変化から, 脊髄運動細胞の興奮性を抑制 し, その結果, $\mathrm{H}$ 波の $\mathrm{M}$ 波に対する最大振幅比が低值 したものと考えられる。そのため, 本研究の結果は, 先行研究を支持する結果が得られたものと解釈できる。

しかし, 本研究はヒラメ筋にターゲットを絞った即 時的効果の検証であったため, 実際の基本動作やス ポーツ動作などで関節運動を行う際は多数の筋が関与 することを考慮すると，パフォーマンス評価等を加え， 様々な視点からその効果を検討 ${ }^{24,25)}$ していく必要性が あると思われる。

\section{引用文献}

1 ）黑川幸雄，高橋正明，鶴見隆正：高齢者の理学療法. 三輪 書店, 東京, 2002，2-6。

2 ）厚生労働省：平成24年簡易生命表の概況。ぎょうせい，東 京, 2013, 1 - 15 .

3 ）鈴木重行, 平野幸伸, 鈴木敏和：ID ストレッチング第 2 版. 三輪書店, 東京, 2006, 2-46.

4 ) Avela J, Kyrolainen H, Komi PV: Altered reflex sensitivity after repeated and prolonged passive muscle stretching. J Appl Physiol, 1999, 86: 1283-1291.

5 ) Kokkonen J, Nelson AG, Cornwel A: Acute muscle stretching inhibits maximal strength performance. Res Q Exerc Sport, 1998, 69: 411-415.

6 ) Guissard N, Duchateau j: Effect of static stretch training on neuro and mechanical properties of the human planterflexor muscles. Muscle Nerve, 2004, 29(2): 248-255.

7 ) Cramer JT, Housh TJ, Weir JP, et al.: The acute effects of static stretching on peak torque,mean power output, electromyography, and mechanomyography. Eur J Appl Physiol, 2005, 93(5-6): 530-539.

8 ) Morse CI, Degens H, Seynnes OR, et al.: The acute effect of stretching on the passive stiffness of the human gastrocnemius muscle tendon unit. J Appl Physiol, 2008, 586: 97-106.

9 ) Yamaguti T, Ishii K, Yamanaka M, et al.: Effect of static stretching for 30 seconds and dynamic stretching on leg extension power. J Strength Cond Res, 2006, 19: 677-683.

10) Behm DG, Bambury A, Cahill F, et al.: Effect of acute static stretching on force, balance, reaction time, and movement time. Med Sci Sports Exerc, 2004, 36(8): 1397-1402.

11）鈴木重行：筋・筋膜性疼痛に対する理学療法の画像による 効果検証の試み。理学療法学, 2005, 32:32-33.

12）影山滋久：Warming up（Cool down）における Stretch お
よび Jogging の効果について（カラーサーモグラフィーを 用いて)。デサントスポーツ科学, 1996, 3 : 306-308.

13）森谷敏夫：ストレッチングによる筋痛の生理学的効果に対 する電気生理学的解明. デサントスポーツ科学, 1987, $8: 212-219$.

14）山下敏彦, 関根将利, 竹林庸雄・他：ストレッチングの生 理学ー筋伸張が神経筋伝達機能に及ぼす影響一。運動・物 理療法, 2001, 12:20-26

15）中村浩一, 向井義人, 兒玉隆之：ID ストレッチングが心 身に及ぼす影響。理学療法科学，2011，26(1)：13-17.

16) Marsh D, Sleivert G: Effect of precooling on high intensity cycling performance. Br J Sports Med, 1999, 33: 393-397.

17) Hoffren M, Isikawa M, Komi PV: Age-related neuromuscular function during drop jumps. J Appl Physiol, 2007, 103: 1276-1283

18）千野直一：臨床筋電図 - 電気診断学入門第 6 版, 医学書院, 東京, 2005, pp56-81.

19) Funase K, Higashi T, Sakakibara A, et al.: Neural mechanism underlying the H-reflex inhibition during static muscle stretching. Adv Exerc Sport Physiol, 2003, 9(4): 119-127.

20) Bakheit AM, Maynard V, Shaw S: The effects of isotonic muscle stretch on the excitability of the spinal alpha motor neurons in patients with muscle spasticity. Eur J Neurol, 2005, 12(9): 719-724.

21) Morse CI, Degens H, Seynnes OR, et al: The acute effect of stretching on the passive stiffness of the human gastrocnemius muscle tendon unit. J Appl Physiol, 2008, 586(1): 97106.

22) Herda TJ, Costa PB, Walter AA, et al.: Effects of two modes of static stretching on muscle strength and stiffness. Med Sci Sports Exerc, 2011, 43(13): 1777-1784.

23) Magnusson SP, Simonsen EB, Aagaard P, et al.: Viscoelastic stress relaxation during static stretch in human skeletal muscle in the absence of EMG activity. Scand J Med J Sci Sports, 1996, 6(6): 323-328.

24) Reid DA, McNair PJ: Passive force, angle, and stiffness changes after stretching of hamstring muscles. Med Sci Sports Exerc, 2004, 36(11): 1944-1948.

25) Stewart M, Adams R, Alonso A, et al.: Warm-up or stretch as preparation for sprint performance? J Med Sci Sport, 2007, 10(6): 403-410. 